\title{
Home gardens: a promising approach to enhance household food security and wellbeing
}

\author{
Dilrukshi Hashini Galhena*, Russell Freed and Karim M Maredia
}

\begin{abstract}
With the global population expected to reach over 9 billion by 2050, there is a continuous need to increase food production and buffer stocks. In this scenario, countries around the world, especially developing countries where the pervasiveness of hunger and food scarcity is more acute, are resorting to various counter strategies to meet the growing demand and to avert food insecurity and famine. Over the recent years there has been growing interest to strengthen and intensify local food production in order to mitigate the adverse effect of global food shocks and food price volatilities. Consequently, there is much attention towards home gardens as a strategy to enhance household food security and nutrition. Home gardens are an integral part of local food systems and the agricultural landscape of developing countries all over the world and have endured the test of time.

Through a rigorous literature review, this paper first examines definitions and characteristics of home gardens and then provides a global review of their social, economic, and environmental contributions to communities in various socio-economic contexts. Many of the compositions on home gardens share research and experiences of developing countries in Africa, Asia, and Latin America. These studies recognize positive impacts of home gardens towards addressing food insecurity and malnutrition as well as providing additional benefits such as income and livelihood opportunities for resource-poor families and delivering a number of ecosystem services. However, only a handful of case studies were found on post-crisis settings. While providing a general overview of some of these studies, this review investigates the home garden experiences of post-conflict Sri Lanka, where home gardening has been practiced for centuries. While emphasizing multiple benefits, we also highlight constraints to home garden food production. In conclusion, we emphasize the need for more research and empirical data to appraise the role of home gardens in crisis and post-crisis situations, as well as assessing their economic value and their impacts on food security, nutrition, economic growth, and gender issues.
\end{abstract}

Keywords: Home gardens, Food security, Livelihood, Post-conflict, Sri Lanka

\section{Introduction}

The vast majority of hungry and malnourished people live in developing countries under sub-standard living conditions [1] and over half a billion of the global population suffer from chronic food insecurity ${ }^{a}$. With the global population expected to reach over 9 billion by 2050 , there will be a continuous need to increase food production and buffer stocks to meet the growing demand and efficiently cope with volatilities in food production and prices. It has been projected that global food production will need to increase by $70 \%$ in order to meet the average daily caloric requirement of the world's

\footnotetext{
* Correspondence: galhenad@msu.edu

College of Agriculture and Natural Resources (CANR), Michigan State University, East Lansing, Ml 48824, USA
}

population in $2050^{\mathrm{b}}$. Moreover, the need for interventions are stressed as the resources available for food production including land, water, labor and credit - are becoming scarce and costly. The drive for agricultural innovation is further convoluted by the growing issues of climate change and natural resource degradation.

Multiple strategies are required to address the issue of food production and food security ${ }^{\mathrm{c}}$. The choice of feasible approaches hinges on the existing social, political, and economic conditions and resources available to design and implement the intervention. Home gardens are a time-tested local strategy that are widely adopted and practiced in various circumstances by local communities with limited resources and institutional support. It is evident from the literature that home gardens are a part 
of the agriculture and food production systems in many developing countries and are widely used as a remedy to alleviate hunger and malnutrition in the face of a global food crisis [2].

Globally, home gardens have been documented as an important supplemental source contributing to food and nutritional security and livelihoods. 'Food production on small plots adjacent to human settlements is the oldest and most enduring form of cultivation' [3]. For centuries, home gardens have been an integral component of family farming and local food systems. Home gardening is an ancient and widespread practice all over the world. In the literature, home gardens are classified as mixed, kitchen, backyard, farmyard, compound or homestead garden [4-7].

This paper presents the developing country experiences of home gardens and looks at the specific case of post-conflict Sri Lanka ${ }^{\mathrm{d}}$. An extensive literature search was conducted through the review of over 100 publications, reports, and book chapters, covering various aspects of home gardening to develop the theoretical framework. The inherent characteristics of home gardens as well as the contextual attributes, benefits, and constraints captured in the literature are summarized in the following sections.

\section{About home gardens}

Home gardens are found in both rural and urban areas in predominantly small-scale subsistence agricultural systems [8]. The very beginning of modern agriculture can be dated back to subsistence production systems that began in small garden plots around the household. These gardens have persistently endured the test of time and continue to play an important role in providing food and income for the family [9]. Since the early studies of home gardens in the 1930s by the Dutch scholars Osche and Terra on mixed gardens in Java, Indonesia [10], there has been extensive contributions to the subject synthesizing definitions, species inventories, functions, structural characteristics, composition, socio-economic, and cultural relevance. Home gardens are defined in multiple ways highlighting various aspects based on the context or emphasis and objectives of the research [11]. Gupta pointed out that the background and gender of the researcher or scientist may also bias their perception on home gardens and may not entirely reflect the opinion of the family involved in home gardening activities [12].

\section{Definition of home gardening}

Relying on research and observations on home gardens in developing and developed countries in five continents, Ninez formulated the following definition [13]:
'The household garden is a small-scale production system supplying plant and animal consumption and utilitarian items either not obtainable, affordable, or readily available through retail markets, field cultivation, hunting, gathering, fishing, and wage earning. Household gardens tend to be located close to dwelling for security, convenience, and special care. They occupy land marginal to field production and labor marginal to major household economic activities. Featuring ecologically adapted and complementary species, household gardens are marked by low capital input and simple technology.'

Generally, home gardening refers to the cultivation of a small portion of land which may be around the household or within walking distance from the family home [14]. Home gardens can be described as a mixed cropping system that encompasses vegetables, fruits, plantation crops, spices, herbs, ornamental and medicinal plants as well as livestock that can serve as a supplementary source of food and income. Fresco and Westphal [15] specify home gardens as a cropping system composed of soil, crops, weeds, pathogens and insects that converts resource inputs - solar energy, water, nutrients, labor, etc. - into food, feed, fuel, fiber and pharmaceuticals. Kumar and Nair [16], while acknowledging that there is no standard definition for 'a home garden', summarize the shared perception by referring to it as '...an intimate, multi-story combinations of various trees and crops, sometimes in association with domestic animals, around homesteads', and add that home garden cultivation is fully or partially committed for vegetables, fruits, and herbs primarily for domestic consumption.

Adding to this, others have described a home garden as a well-defined, multi-storied and multi-use area near the family dwelling that serves as a small-scale supplementary food production system maintained by the household members, and one that encompasses a diverse array of plant and animal species that mimics the natural eco-system [11,17-19].

\section{Characteristics of a home garden}

Michelle and Hanstad [20] list five intrinsic characteristics of home gardens: 1) are located near the residence; 2) contain a high diversity of plants; 3) production is supplemental rather than a main source of family consumption and income; 4) occupy a small area [21]; and 5) are a production system that the poor can easily enter at some level [9].

There is a vast body of literature presenting research and case studies focusing on the role of home gardens as agroforestry or food production systems, or a combination of both. Home gardens are ecologically divided into two categories: tropical and temperate [13]. Much of the 
literature focuses on home gardens in the tropical areas in Central and South America [22-25]. There is also a substantial interest for home gardens in South and South-East Asia [26-29] and Africa [30-34]. Conversely, only a few documented studies exist on home gardens from temperate regions [35-38] and from developed countries [32,39-42].

Ninez [13] lists general tendencies with respect to home garden food production systems based on 15 type-specific characteristics adopted from Ruthenberg [5] (Table 1), and presents an ethnographical synthesis of home gardens across the globe. Home gardens are commonly established on lands that are marginal or not suitable for field crops or forage cultivation because of their size, topography, or location [11]. The specific size of a home garden varies from household to household and, normally, their average size is less than that of the arable land owned by the household. However, this may not hold true for those families that do not own agricultural land and for the landless. New innovations and techniques have made home gardening possible even for the families that have very little land or no land at all [43]. The home gardens may be delimited by physical demarcations such as live fences or hedges, fences, ditches or boundaries established through mutual understanding. Application of kitchen waste, animal manure, and other organic residues has been a practice amongst home gardeners and this exercise has helped to considerably increase the productivity and fertility of these gardens $[11,44,45]$.

While some similarities exist across the board, each home garden is unique in structure, functionality, composition, and appearance $[13,46-48]$ as they depend on

Table 1 The key characteristics of a typical home garden

\begin{tabular}{ll}
\hline Characteristic & General practice \\
\hline Species density & High \\
Species type & Staples, vegetables, fruits, medicinal plants \\
Production objective & Home consumption \\
Labor source & Family (women, elderly, children) \\
Labor requirements & Part-time \\
Harvest frequency & Daily, seasonal \\
Space utilization & Horizontal and vertical \\
Location & Near dwelling \\
Cropping pattern & Irregular and row \\
Technology & Simple hand tools \\
Input-cost & Low \\
Distribution & Rural and urban areas \\
Skills & Gardening and horticultural skills \\
Assistance & None or minor \\
\hline
\end{tabular}

Source: Niñez [3]. the natural ecology of the location, available family resources such as labor, and the skills, preferences, and enthusiasm of family members $[45,49,50]$. Home garden cultivation tends to be quite dynamic $[17,18]$. The decisions related to the selection of crops, procuring inputs, harvesting, management, and so forth are mostly driven by the consumption and income generation needs of the household $[27,45]$. A study from Indonesia observed that the structure, composition, intensity of cultivation, and diversity of home gardens can be subjected to the socioeconomic status of the household [51]. For instance, as the families became economically stable their cultivation shifted from staples to horticultural crops and some families began to raise livestock. Based on the economics of the household, Niñez [13] differentiated two types of home gardens: 1) subsistence gardens and 2) budget gardens. Access to planting material and social capital are noted as important attributes to species diversity in gardens [52]. Collectively, the ecological potential, economic status, and social elements influence the presence of food and non-food crops and animals in the garden [28,53]. Additionally, Moreno-Black and colleagues [54] identified that limitations resulting from factors such as opportunities for off-farm employment and family structure as well as local customs influence the development and composition of the gardens.

The home garden frequently uses family labor [18] women, children, and elders are of particular importance in their management [46,48,55-57] - but, depending on the economic capacity and affordability, households may hire wage laborers to cultivate and maintain the home garden that in turn affect the composition and intensity of home garden activities $[22,55,56]$. Like any other food production system, home gardens may be vulnerable to harsh environmental conditions such as drought and floods [57,58]. Despite the fact that home gardening activities demand a lesser amount of horticultural and agronomic know-how, crop losses and other negative implications can be reduced when the household members are empowered with better skills and knowledge [59].

\section{Experiences of home gardens from developing countries}

Home gardens have been an integral part of local food systems in developing countries around the world. Many studies provide descriptive evidence and analysis of home gardens in developing countries in Asia, Africa, and Latin America and pinpoint their numerous benefits to communities and families. They encapsulate perpetual small-scaled subsistence agricultural systems established by the households to obtain and supplement the food requirements of the family. Home gardens are mainly intended to grow and produce food items for family consumption, but they can be diversified to produce outputs that have multiple uses including indigenous 
medicine and home remedies for certain illnesses, kindling and alternative fuel source, manure, building material, and animal feed. Chris Landon-Lane [60] provides an overview of the benefits of home gardens (Table 2) and describes home gardens as a 'place for innovation' with the potential to improve the livelihood of peri-urban and rural communities. In-depth exploration of past and more recent compositions on home gardens worldwide not only affirms Landon-Lane's insight but also recognize additional advantages. We broadly categorized benefits of home gardening into three components: (1) social; (2) economic; and (3) environmental benefits. These benefits are presented and explained through the vast experiences on home gardens from developing nations around the world.

\section{Social benefits}

\section{Enhancing food and nutritional security}

Reviews of studies from various countries reveal that the degree and combination socio-cultural impacts on societies engaged in home gardening vary across the board. Multiple social benefits of home gardens include enhancing food and nutritional security in many socio-economic and political situations, improving family health and human capacity, empowering women, promoting social justice and equity, and preserving indigenous knowledge and culture [20].

The most fundamental social benefit of home gardens stems from their direct contributions to household food security by increasing availability, accessibility, and utilization of food products ${ }^{\mathrm{e}}$. Home gardens are maintained for easy access to fresh plant and animal food sources in both rural and urban locales. Food items from home gardens add substantially to the family energy and nutritive requirements on a continuous basis. A pioneering research study on home gardens conducted by Ochse and Terra in the early 1930s [10] states that home gardens led to $18 \%$ of the caloric and $14 \%$ of the protein consumption by households in Kutowinangun, Indonesia. Subsequent studies on the Javanese home gardens point out a direct link between successful home gardens and households' nutritional status [61], and observe an increase in households' food consumption with

\section{Table 2 The key benefits of home gardening}

\footnotetext{
- Improved food security

- Increased availability of food and better nutrition through food diversity

- Income and enhanced rural employment through additional or off-season production

- Decreased risk through diversification;

- Environmental benefits from recycling water and waste nutrients, controlling shade, dust and erosion, and maintaining or increasing local biodiversity
}

Source: Landon-Lane [60]. intensification of home food production [62]. Javanese experiences illustrating the potential of home gardens to add to households' food supply and nutrition [13,21], as well as their eminence as multi-storied agro-ecosystem [55,63] in the tropics, heightened the global attention towards home gardens.

Foods from home gardens varied from horticultural crops to roots to palm and animal products; further plants from the gardens are also used as spices, herbs, medicines, and fodder for the animals [53,64-67]. Although home gardens are not generally reputed as a staple crop production base, Thaman [65] documented that Pacific Islanders obtained their main staple root crops from home gardens. Similar reports were found from Nepal [19], Yucatan Peninsula [66], Bangladesh [67], Peru [68], Ghana [69], and Zimbabwe [56]. Resource-poor families often depended more on home gardens for their food staples and secondary staples than those endowed with a fair amount of assets and resources such as land and capital [51,70]. For poor and marginalized families unable to afford expensive animal products to fulfill their nutritional needs, home gardens offer a cheap source of nutritive foods [71]. Through gardening, households can have better access to a diversity of plant and animal food items that lead to an overall increase in dietary intake and boost the bioavailability and absorption of essential nutrients [72].

As stated by Marsh [9], home gardens provide easy day-to-day access to an assortment of fresh and nutritious foods for the household and accordingly those homes obtained more than $50 \%$ of the vegetables, fruits, tubers, and yams from their garden. Supporting this premise, different studies conclude that, while adding to the caloric quantity, home gardens supplement staple-based diet with a significant portion of proteins [48], vitamins [16], and minerals [73], leading to an enriched and balanced diet $[74,75]$ particularly for growing children and mothers [76]. Additionally, plants from the gardens - especially spices and herbs - are used as flavor enhancers, teas, and condiments [77]. Recently, countries like Bangladesh have been successful in increasing the availability and consumption of vitamin A-rich food items through national home gardening programs [72].

Furthermore, the integration of livestock and poultry activities into home gardening reinforces food and nutritional security for the families as milk, eggs, and meat from home-raised animals provided the main and, in many instances, the only source of animal protein [66]. In some places, home gardeners are also engaged in mushroom cultivation and beekeeping [75] and even small fresh water fish ponds are incorporated into the garden space adding to the share of proteins and other nutrients available for the family [27]. 
Evidence from around the world suggests that home gardens can be a versatile option to address food insecurity in various challenging situations, and thus they have attracted sponsorship by numerous government and nongovernmental organizations. Consequently, home garden production has significantly increased in the country and has been instrumental in reducing 'hidden hunger' and disease cause by micronutrient deficiency. In an attempt to assess the dynamics of home garden evolution in Java and Sulawesi in Indonesia, Wiersum [51] notes that home gardens make available a small but continuous flow of subsistence food products for the household. Also, home gardens provide the main source of staple food for people in heavily degraded and densely populated areas with limited croplands [44,78].

Home gardens can ensure food to underprivileged and resources-poor households as they can be established and maintained within a small patch of land or with no land using a few inputs [20,43]. A study of home gardens in Cuba reveals that they were used as a strategy to increase resilience and ensure food security in the face of economic crisis and political isolation [79]. To mitigate recurring food shortage and malnutrition, Cuban households obtained basic staple foods (rice and beans) through rations, but the households relied on their home gardens to obtain additional produce to diversify the family diet [80]. Ensuring a reliable and convenient source of food, fiber, and fuel for the family, they are viewed as a robust food system in circumstances where population pressures and numerous resource limitations persist $[81,82]$. In the Peruvian capital of Lima, home gardening has led to nutritional benefits to families living in slum areas by increasing the availability of carbohydrates as well as nutrient-rich vegetables and fruits that are not economically accessible for poor slum dwellers [83].

The Global Hunger Index specified that the lack of political stability has escalated hunger and poverty in countries affected by conflicts [84]. Similarly, environmental disaster can also have devastating impacts on communities and disable food production systems [85]. Even though there are only a few published narratives, home gardens have been proposed as an option for food and nutritional security in disaster, conflict, and other post-crisis situations ${ }^{\mathrm{f}}[9,45,86]$. Home gardens based on enset and coffee are an integrated farming system that not only provide subsistence and complementary food products for Ethiopian families, especially during famines, but also provide the primary means of employment for the household [78].

Tajikistan became independent from the Soviet Union in 1991 but was plagued by a civil war soon after. Rowe [7] showed that, during the post-soviet era, Tajik families tormented by civil war, agricultural downfall, and drought heavily depended on their gardens for food. This trend still continues, and home gardens continue to significantly supplement household food security and sustenance. In recent years, several countries transitioning towards peace and stability and those that are recovering from natural disaster have been adopting policies that support home gardening to reduce the prevalence and severity of hunger and malnutrition $[45,87]$.

Bandarin et. al. [88] point out that, in a post-conflict setting, assistance and reconciliation mechanisms work best and result in environmental, social and economic benefits when there is a cultural or traditional linkage between the target population and the intervention. Hence, home garden projects offer a realistic solution as in most countries home gardening is a regular day-to-day activity amongst the household, especially for women. In addition, home gardens when properly managed provide a four-in-one solution to the food and nutrition problem by increasing household food availability, enabling greater physical, economic and social access, providing an array of nutrients, and protecting and buffering the household against food shortages.

\section{Improving health}

Plants are an important source of medicine for humans and livestock and are used as biological pesticides to protect crops from diseases and pest infestations. Herbs and medicinal plants are grown in home gardens all over the world, and in developing countries nearly $80 \%$ of the people use them to treat various illnesses, diseases, and also to improve their health conditions [89]. A generous portion of the plants found in home gardens have some medicinal value and they can be used to treat many common health problems in a cost-effective manner. For instance, Perera and Rajapksa, in their assessment of Kandyan gardens in Sri Lanka [90], note that out of the 125 plant species found about 30\% were exclusively used for medicinal uses and about $12 \%$ for medical and other purposes. Medicinal plants were documented to be an important plant group second only to high-value species in Sri Lanka [90] and in Bangladesh [91]. Home gardens in Bukoba district of Tanzania contained plant species grown entirely for medicinal purposes [92]. Around 70\% of the plant species identified in forests and gardens in the Yucatan had a medicinal use [93], and in traditional Mayan home gardens nine species of the 77 useful plants found were exclusively used for medicinal purposes and 26 species had mixed uses as medicines, food, spices, and ornamentals [94].

Food insecurity and economic hardships force people to consume less and to settle for food that is of low nutritional quality. Adverse health effects due to inadequate intake of basic macronutrients are further compounded by deficiencies in micronutrients such as 
vitamins and minerals. More than 35\% of the fatalities worldwide are caused by factors attributed to nutritional deficits [95]. Amongst them, vitamin A deficiency is a major health issue in many low-income countries and pose serious health problems, particularly for pregnant women and their babies and growing children. Reports indicate more than 7 million women suffering from complications due to vitamin A insufficiency [96] and cause 6 to $8 \%$ of the deaths amongst children under the age of 5 years in Africa and Asia [95]. In some countries where this problem is acute, homestead food production programs have been launched to assist and address vitamin A deficiency and to improve the quality of diet by facilitating a year-round production of vegetables and fruits [85].

The global incidence of anemia is primarily attributed to iron deficiency. Iron insufficiency elevates the risk of mortality during pregnancy by $20 \%$ [97]. Moreover, estimates suggest that nearly one-third of the global population live in countries with high zinc deficiency [98]. Micronutrient deficiency can raise the vulnerability to other infectious diseases and the risks of mortality due to illnesses such as diarrhea, pneumonia, malaria, and measles [99]. It may also lead to poor physical and cognitive development and impairment of motor skills in young children as well as other short-term and long-term health effects. Furthermore, a vicarious cycle of undesirable socio-economic effects can be triggered as peoples' ability to actively engage in physical and economic activities are hindered by illness, disability, and reduced life expectancy. In different contexts, home gardening initiatives have been proposed and implemented as potential strategies to address health issues resulting from malnutrition $[100,101]$. Although the opportunity is real, minimal efforts have been made to identify and maximize the gross benefits of home gardening for better health.

\section{Uplifting the status of women}

In many cultures, women play an important role in food production but at times their worth is somewhat undermined. They are also active in home gardening, though their involvement in the home garden tends to be determined by socio-cultural norms [20]. In most scenarios women's contribution to household food production is immense, but this does not imply that home gardening is predominantly a female activity. Women's participation and responsibilities in home gardening varies across cultures, including land preparation, planting, weeding, harvesting, and marketing [54,102,103]. In fact, in some cultures, women are the sole caretakers of household gardens [35,72] while, in others, they play more or less a supportive role [11]. Howard's 2006 analysis [104] of 13 home gardens case studies in South America revealed that women are the main managers of home gardens across the region. Home gardening activities are vital and fit well with their day-to-day domestic activities and employment patterns along with their cultural and aesthetic values. On the other hand, in the Indonesian context women take part during planting and harvesting [49] and, in Sri Lanka, they provide labor during peak times [55]. Regardless, particularly for women and disadvantaged groups, home gardening is an avenue for social and economic enrichment.

Home gardens stimulate social change and development. Amongst the Achuar Indian community in the upper Amazon, a woman's ability to maintain a lush home garden not only demonstrates her agronomic competency but also her status in society [105]. Similarly, for the Saraguro women of the Andes, a plentiful garden help elevates a woman's social eminence and demonstrates her commitment to the family's wellbeing [25]. Based on a study conducted in Senegal by Brun and colleagues [106], evaluating the food and nutritional impact of home gardening, it was found that, although the gardens did not make a major contribution to food consumption and nutrition, they were instrumental in improving the women's income and social status as well as their awareness of evolving food habits in urban areas. For some women, sales of garden products are often the only sources of income or livelihood [9]. In Tajikistan, where many of the men were killed during the civil war or have migrated to Russia and other countries for employment, women, elders and children have been providing invaluable family labor and resources to local agricultural economy. Kitchen gardens, as they are referred to by Rowe [7], are very important especially for women-headed families in terms of meeting their everyday food consumption needs and generating income. In fact, nearly half of the food consumed at home and one-third of the food sold in the market came from these garden lots. Other studies have shown that, in situations where women are leading home gardens, there has been improvement to household nutrition, especially child nutrition [72,107].

Through home gardening women have developed proficiency related to plants and garden practices that helps them become better home and environment managers. Their labor is indispensable to maintain the garden and to help keep production cost low. As home managers, women have useful knowledge of numerous domestic needs. By their involvement in the production process, they are able to meet family needs more easily and economically [44]. Home gardeners in Peru indicated that women gardeners are inclined to produce food primarily for family consumption while men gardeners typically focus on high value crops for marketing [83]. While home gardens provide a respectable path for women to contribute to household subsistence, eminence, and character, they 
hold a greater socio-cultural and spiritual importance for women [104]. Furthermore, they are a key source of gardening knowledge and information [105].

Research suggests that, in some societies and cultures, a woman's role in family decision making is rather limited; however, many accounts confirm that when it comes to home gardening women tend to have more autonomy and decision making capabilities [108]. Moreno-Black and colleagues [54] conducted a study of 49 women's home gardens in Northeastern Thailand where the rural women constantly indicated that they were the key decision makers and carried out most of the activities of the home gardens.

\section{Preserving indigenous knowledge and building integrated societies}

Home gardens consist of a variety of components and species that represent social and traditional aspects of different societies. This rich indigenous culture and communal knowledge base is expressed through home gardening by the selection of plants and animal species as well as the farming practices used by the local community [16,70]. Home gardens serve as a valuable repository for preserving and transferring indigenous crops and livestock species, production knowledge and the skills from one generation to another [109-111].

Interactions in and around the home garden create and reinforce social status and ties between the household and the community. Home gardeners habitually exchange or gift planting materials, vegetables, fruits, leaves, herbals and medicinal plants for social, cultural, and religious purposes $[109,110]$. Such interactions are essential for social integration and building social capital. The social dimension of home gardening is yet not fully explored.

\section{Economic benefits}

The economic benefits of home gardens go beyond food and nutritional security and subsistence, especially for resource-poor families. Bibliographic evidence suggests that home gardens contribute to income generation, improved livelihoods, and household economic welfare as well as promoting entrepreneurship and rural development $[111,112]$. Through the review of a number of case studies, Mitchell and Hanstad [20] assert that home gardens can contribute to household economic well-being in several ways: garden products can be sold to earn additional income $[17,48,83]$; gardening activities can be developed into a small cottage industry; and earnings from the sale of home garden products and the savings from consuming home-grown food products can lead to more disposable income that can be used for other domestic purposes. Studies from Nepal, Cambodia, and Papua New Guinea report that the income generated from the sale of home garden fruits, vegetables, and livestock products allowed households to use the proceeds to purchase additional food items as well as for savings, education, and other services $[85,113]$. Families in mountain areas of Vietnam were able to generate more than $22 \%$ of their cash income through home-gardening activities [111].

Home gardens are widely promoted in many countries as a mechanism to avert poverty and as a source of income for subsistence families in developing countries. Although home gardens are viewed as subsistence-low production systems, they can be structured to be more efficient commercial enterprises by growing high-value crops and animal husbandry [43]. A number of research studies have focused on evaluating the potential or real economic contribution to the household and local economy as well as social development [114]. A study from Southeastern Nigeria reported that tree crops and livestock produced in home gardens accounted for more than $60 \%$ of household income [115]. In many cases the sale of produce from home gardens improves the financial status of the family providing additional income, while contributing social and cultural amelioration [116]. The fact that home production is less cost-intensive and requires fewer inputs and investment is extremely important for resource-poor families that have limited access to production inputs. Yet it has been assessed that moderately rigorous crop and livestock production in home gardens can generate as much revenue per unit area as field crop production $[9,62]$. Where land constraints exist, innovative tools have been used to make efficient use of limited space [43]. Also, livestock housed in gardens diversify risk due to crop losses and provide a cash buffer and asset to the household [117].

\section{Environmental benefits}

Home gardens provide multiple environmental and ecological benefits. They serve as the primary unit that initiates and utilizes ecologically friendly approaches for food production while conserving biodiversity and natural resources. Home gardens are usually diverse and contain a rich composition of plant and animal species. Hence they make interesting cases for ethno-botanical studies [110,118].

Gardens are complex and may resemble ecological agricultural production systems that sponsor biodiversity conservation. The rich diversity and composition of species and the dense distribution of faunal and floral strata denote extraordinary features of home garden ecology [20,46]. Buchmann's 2009 assessment [79] of 25 home gardens in Central Cuba noted 182 plant species. Other reports from around the world also identify a significant concentration of plants used as vegetables, fruits, herbs, medicines, yams, and spices [78,114]. Home gardens also contain a wide spectrum of plant species, some of which are landraces, rare or threatened species, 
and specific cultivars selected for a set of desirable traits [119]. Thus they become ideal sites for in situ conservation of biodiversity and genetic material $[111,120]$.

Home gardens also provide a number of ecosystem services such as habitats for animals and other beneficial organisms, nutrient recycling, reduced soil erosion, and enhanced pollination [121]. The high density of plants within the home garden provides the ideal environment and refuge for wildlife species such as birds, small mammals, reptiles, and insects [122]. Calvet-Mir et. al. [112] highlight a number of ecosystems services provided by home gardens such as production of quality food, maintenance of landraces, cultural services, pest control, and pollination. They conclude that the most important ecosystems services provided by home gardens differ from large-scale and commercial agriculture.

Nutrient cycling is another ecological benefit of home gardens $[120,123]$. The abundance of plant and animal litter and continuous recycling of organic soil matter contributes to a highly efficient nutrient cycling system. Another potential benefit of home gardens is the reduction of soil erosion and land conservation [70,124]. The attraction of honey bees provides added benefits including improved pollination and increased fruit dispersal [64].

Individuals of the household, animals, and plants all maintain a symbiotic relationship within the home gardens. For instance, the plants and animals provide food and other benefits for the family and the family in turn takes care of the home gardens. Plant materials are used as fodder for the animals and animal manure is incorporated into the compost to fertilize plants, hence reducing the need for chemical fertilizer [20]. Livestock and poultry manure can add a significant amount of organic soil matter, nitrogen, potassium, and phosphorus into the soil. The integration of livestock activities into home gardening can expedite nutrient cycling in ecosystem and help retain moisture [125].

\section{Home gardens in Sri Lanka}

The economy of Sri Lanka is founded on agriculture. More than 35\% of the 20 million people of Sri Lanka are engaged directly or indirectly in the agrarian sectors. Home gardening has been a long-standing practice among the rural and urban households in Sri Lanka for centuries [55]. Despite the traditional basis for home gardening, over the recent years national policies have focused on promoting home gardening in the country. Currently, two national initiatives are underway and are receiving notable patronage from the government for the initiation of a countrywide food production drive to establish one million home gardens across the island ${ }^{g}$. The programs highlight the key role home gardens play in the face of food insecurity, economic downturn and malnutrition by providing a diversified source of food and a way of generating income.

In spite of the growing interest in home gardening, literature discussing home gardens in Sri Lanka is rather limited. The bulk of the available excerpts almost exclusively focuses on Kandyan Gardens, also known as Kandyan Forest Gardens (KFG). KFG are a common traditional agroforestry system found in the wet central hills in Sri Lanka. They encompass a mixed cropping system, which includes a diverse collection of economically valuable perennial and semi-perennial crops situated around the household [126] along with animal species that were raised to suit the necessities of the family, the environment, and the recommendations by scientists and extension workers [127].

One of the earliest studies on KFG in Sri Lanka was published by McConnell and Dharmapala [126]. From a survey of 30 KFGs established through the use of a farming systems approach they conclude that, although in the short-run KFG were not as productive and profitable as the commercial farming systems, they lead to multiple benefits over time. Jacob and Alles [55] differentiate KFGs from other mixed forest-gardening systems found in South Asia and South-east Asia with respect to the diversity of plants grown. They also stated that these garden systems improved the well-being of people who nurtured them through the provision of various food products and timber, livelihood opportunities, and sustainability of the production system. Furthermoe, they emphasized the need to inspect existing agronomic practices and to design feasible models that can improve the productivity per unit of land.

Perera and Rajapaksa [90] characterize various components of KFGs based on ownership, structure, species composition, livestock composition, and management practices. Their baseline survey of 50 randomly selected gardens in the Kandy District showed that the various species in the KFG had numerous uses including food, cash, timber, fuel wood, construction material, green manure, fodder, medicines, shade, and beautification. KFG also have significant implications to the region in terms of in situ germplasm conservation [128], watershed management [90], preservation of habitat and other ecological contributions [129].

A book by Hochegger [130] offers a comprehensive overview of the ecological, economic, and cultural relevance of KFG in Sri Lanka investigating six locations in the central hills. The Green Movement in Sri Lanka pioneered by Kumarathunga [131] has published a guide on environmentally friendly agriculture with key emphasis on home gardens. This publication has been initially written in the Sinhala language and is in the process of being translated to the Tamil language. The guide provides step-by-step instructions to home gardeners and farmers 
on environmentally friendly cultivation and management practices and strategies to boost the efficiency of small agricultural production systems.

Ranasinghe [43] has developed a detailed manual drawing on the ideas of family business gardens and low/no-space agriculture. This manual was shaped primarily to attract urban households to develop their home crop production into a small agribusiness. In addition this publication attempted to reach a wider audience that includes professionals, non-professionals, entrepreneurs, as well as policy makers concerned with issues related to food and nutritional security in the face of limited resources such as land. It highlights that, through improved management, home garden cultivations can be transformed into agricultural ventures through the systematic adoption of economical and eco-friendly technologies and interventions.

\section{Constraints and opportunities}

While there are multiple benefits of home gardening for developing countries, the literature also reveals the key constraints to the productivity and sustainability of home gardens and makes recommendations for improving the home gardens and making them a viable and sustainable enterprise. Hoogerbrugge and Fresco [11] and Mitchell and Hanstad [20] provide a review of key constraints to home gardening. Among several constraints, they identified the access to suitable and sufficient land to establish a home garden along with lack of ownership and usage rights of some form as the most important limiting factors. The other constraints include access to capital or credit, access to water, seeds and planting materials, weak extension and advisory services, access to labor, and access to markets. The cultural acceptance of home gardening is also an important constraint. Table 3 summarizes the most common constraints to home gardening specified in literature by Hoogerbrugge and Fresco and others.

\section{Conclusions}

Overall, the literature review supports the inclusion and promotion of home gardens as an eco-friendly sustainable agricultural practice to improve food security and enhance economic growth.

The structure, functions, and contributions of home gardens vary in geographic regions. The literature shows that home gardens fulfill social, cultural and economic needs, while providing a number of ecosystem services. While these benefits are broadly distinguished here for better illustration, these benefits are not mutually exclusive. In the real world, there is substantial overlap and dependence between the various beneficial elements resulting in a bundle of advantages making home gardening initiatives even more attractive.

In the wake of a global food crisis and the soaring food prices, there has been increased emphasis on enhancing and building local food systems. In this context, there is renewed attention to food production and livelihood enhancement through home gardens. However, more empirical evidence on the value and importance of home gardens in conflict and post-conflict situations needs to be researched and documented. There is also a need for research on the cost-benefit analysis of home gardening to determine the economic value and to derive viable models that hold the most promise in diverse circumstances. The areas of nutrition, access to new technologies, extension

Table 3 Selected publications presenting constraints to home gardening

\begin{tabular}{|c|c|}
\hline Constraint & References \\
\hline $\begin{array}{l}\text { Limited access to agricultural inputs such as seeds, planting } \\
\text { material, tools, and capital }\end{array}$ & Brownrigg [21]; Niñez [83]; Talukder et al. [72]; Fernandes and Nair [46] \\
\hline Shortage of land and lack of land tenure security & $\begin{array}{l}\text { Hoogerbrugge and Fresco [11]; Fernandes and Nair [46]; Jose and } \\
\text { Shanmugaratnam [132]; Howard [104] }\end{array}$ \\
\hline Inadequate access to water & Thaman [133]; Niñez [83]; tho Seeth et al. [35] \\
\hline Damage due to insect pests, diseases, animals, and theft & Thaman [133]; Brownrigg [21]; Niñez [83]; Pandey et al. [103] \\
\hline Poor environmental conditions & Howard [104]; Marsh [9] \\
\hline Lack of knowledge, information, and advisory services & Thaman [133]; Hoogerbrugge and Fresco [11] \\
\hline Shortage of family or hired labor & Howard [104]; Fernandes and Nair [46] \\
\hline Poor soil fertility and soil erosion & Howard [104]; Thaman [133] \\
\hline Limited access to quality livestock breeds & Brownrigg [21]; Mitchell and Hanstad [20] \\
\hline Limited marketing opportunities & Howard [104] \\
\hline Excessive post-harvest losses & Okafor and Fernandes [30] \\
\hline Inadequate research and development on home gardens & Evers, et al. [134] \\
\hline Social and cultural Barriers & Marsh [9]; Ninez [83]; Miura et al. [135], Talukder et al. [72] \\
\hline Lack of information on nutritional benefits of home gardening & Miura et al. [135]; Talukder et al. [72] \\
\hline
\end{tabular}


and advisory services, economic and non-economic benefits, women empowerment, and long-term sustainability of home gardens specifically in post-conflict situations need further research.

Recognizing the value and potential of home gardens for enhancing food security and livelihoods, numerous initiates have been launched by governmental, nongovernmental, and international organizations in many developing countries that are providing support and building local capacity to enhance the productivity and also for scaling up home garden activities. In this light, a number of resource materials, manuals, and guides have been developed through various home garden-related projects that can be used to improve and promote home gardening programs to enhance food security $[43,60,87]$.

\section{Endnotes}

${ }^{\mathrm{a}}$ Food insecurity occurs in three forms: chronic food security is the most severe category where a person is unable to consume the minimum amount of food needed for healthy life over a long period usually due to poverty or lack of productive recourses to generate income to purchase food [136]. Other types include transitional (short-term) food insecurity, which is further subdivided into temporary (limited time period due to shocks) and seasonal or cyclical (trend) food insecurity.

${ }^{\mathrm{b}}$ The Food and Agriculture Organization [137] reported an average consumption per person of 3,130 kcal per day by the year 2050 based on their baseline projections. Alexandratos [138] estimated a slightly lower average daily caloric availability per person of $3,047 \mathrm{kcal}$ per day by the year 2050.

${ }^{\mathrm{c}}$ Since its inception in the early 1970s, the concept of food security has undergone many revisions and has held multiple connotations in research and in policy arenas. The two widely adopted conceptualizations are defined by: 1) the Food and Agriculture Organization - 'food security is a situation that exists when all people, at all times, have physical, social and economic access to sufficient, safe and nutritious food that meets their dietary needs and food preferences for an active and healthy life' [139]; and 2) by the United States Department of Agriculture - 'food security for a household means access by all members at all times to enough food for an active, healthy life. Food security includes at a minimum: the ready availability of nutritionally adequate and safe foods; and an assured ability to acquire acceptable foods in socially acceptable ways' [140].

${ }^{d}$ For nearly 30 years, the country underwent erratic disorder and military action that caused substantial destitutions to the political and socio-economic structure in the country as well as the infrastructure. The civil conflict was brought to an end in 2009 by the Sri Lankan government forces.
${ }^{\mathrm{e}}$ As noted earlier there are numerous definitions to food security; nevertheless, these definitions highlight three broad dimensions: food availability, accessibility, and adequacy/utilization [139-141] (FAO, 2003 ). Food availability refers to the supply of food made available through domestic production, net imports, food reserves, donations, etc. Accessibility is ensured when an individual is able to obtain food without any physical, social, or economic barriers. Food adequacy/ utilization is achieved through various biological and non-biological processes that ensure sufficient energy and nutrient intake.

${ }^{\mathrm{f}}$ One general connotation for crisis is defined by Gasser and colleagues [142]. Crisis situations are identified as unique and complex in nature and are due to various factors [141]. At times, crisis is unforeseen and inevitable as in the case of natural disasters - while others may be more protracted and influenced by economic, social, and political changes - such as civil or armed conflict. Irrespective of the origin, crisis adversely affects society by depriving affected groups of their rudimentary and ancillary needs and services including food, shelter, income, health care, security, and infrastructure.

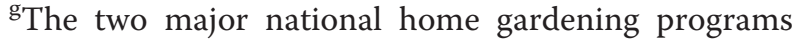
in Sri Lanka are "Api Wavamu, Rata Nagamu" (Let us cultivate to uplift the nation) and "Divinaguma" (Livelihood upliftment). In addition, a number of other regional and village level gardening programs are coordinated and managed by international and non-governmental organizations.

\section{Abbreviation}

KFG: Kandyan forest gardens.

\section{Competing interest}

The authors declare that they have no competing interests.

\section{Authors' contributions}

DHG initiated this review, conducted the bibliographic analysis, and developed the content of this manuscript. RF and KMM contributed to the enhancement of the framework and writing. All authors reviewed and approved the manuscript.

\section{Acknowledgement}

The authors would like to thank the many reviewers for their feedback and suggestions for the early drafts of this manuscript.

Received: 20 February 2013 Accepted: 1 May 2013

Published: 31 May 2013

\section{References}

1. Food and Agriculture Organization of the United Nations and World Food Programme: The State of Food Insecurity in the World - Addressing Food Insecurity in Protracted Crises. Rome, Italy: Food and Agriculture Organization of the United Nations; 2010.

2. Johnson-Welch C, Alemu B, Msaki TP, Sengendo M, Kigutha H, Wolff A: Improving Household Food Security: Institutions, Gender and Integrated Approaches. Davis CA, USA: Paper prepared for the Broadening Access and Strengthening Input Market Systems (BASIS) Collaborative Research Support Project (CRSP); 2000.

3. Niñez VK: Household gardens: theoretical and policy considerations. Agr Syst 1987, 23:167-186. 
4. Terra GJA: Farm systems in southeast Asia. Neth J Agric Sci 1958, 6:157-182.

5. Ruthenberg H: Farming Systems in the Tropics. 3rd edition. Oxford, UK: Clarendon Press; 1980.

6. Puri S, Nair PKR: Agroforestry research for development in India: 25 years of experiences of a national program. Agrofor Sys 2004, 61:437-452.

7. Rowe WC: "Kitchen gardens" in Tajikistan: the economic and cultural importance of small-scale private property in a post-soviet society. Hum Ecol 2009, 37(6):691-703.

8. Nair PKR: An Introduction to Agroforestry. Dordrecht, The Netherlands: Kluwer Academic Publishers; 1993.

9. Marsh R: Building on traditional gardening to improve household food security. Food Nutr Agr 1998, 22:4-14.

10. Ochse JJ, Terra GJA: Research on the Economic and Agricultural Condition and Food Consumption in Koetowinangoen. Landbouw. The Netherlands: Publisher unknown; 1934:10.

11. Hoogerbrugge I, Fresco LO: Homegarden Systems: Agricultural Characteristics and Challenges. London, UK: International Institute for Environment and Development; 1993. Gatekeeper Series No. 39.

12. Gupta AK: Scientists' views of farmers' practices in India: barriers to effective interaction. In Farmer First. Farmer Innovation and Agricultural Research. Edited by Chambers R, Pacey A, Thrupp LA. London, UK: Intermediate Technology Publications; 1989.

13. Niñez VK: Household Gardens: Theoretical Considerations on an Old Survival Strategy. Peru, Lima: International Potato Center; 1984.

14. Odebode OS: Assessment of home gardening as a potential source of household income in Akinyele Local Government Area of Oyo State. Nig J Horticulture Sci 2006, 2:47-55.

15. Fresco LO, Westphal E: A hierarchical classification of farm systems. Exp Agric 1988, 24:399-419.

16. Kumar BM, Nair PKR: The enigma of tropical homegardens. Agrofor Syst 2004, 61:35-152.

17. Eyzaguirre PB, Linares OF: Intorduction. In Homegardens and Agrobiodiversity. Edited by Eyzaguirre PB, Linares OF. Washington DC, USA: Smithsonian Books; 2010:1-28.

18. Sthapit BR, Rana RB, Hue NN, Rijal DR: The diversity of taro and sponge gourds in traditional home gardens in Nepal and Vietnam. In Home Gardens and Agrobiodiversity. Edited by Eyzaguirre PB, Linares OF. Washington DC, USA: Smithsonian Books; 2004:234-254.

19. Krishna GC: Home Gardening as a Household Nutrient Garden. Pokhara, Nepal: Paper presented at Home Gardens in Nepal: Proceeding of a workshop on "Enhancing the contribution of home garden to on-farm management of plant genetic resources and to improve the livelihoods of Nepalese farmers: Lessons learned and policy implications" (2004); 2006.

20. Mitchell R, Hanstad T: Small Homegarden Plots and Sustainable Livelihoods for the Poor. Rome, Italy: LSP Working Paper 11; 2004

21. Brownrigg L: Home Gardening in International Development: What the Literature Shows. Washington DC, USA: The League for International Food Education; 1985

22. Mendez VE, Lok R, Somarriba E: Interdisciplinary analysis of homegardens in Nicaragua: micro-zonation, plant use and socioeconomic importance. Agrofor Syst 2001, 51:85-96.

23. Leiva JM, Azurdia C, Ovando W, López E, Ayala H: Contribution of Home Gardens to in situ Conservation in Traditional Farming Systems-Guatemalan Component. Witzenhausen, Germany: Paper presented at Proceedings of the Second International Home Gardens Workshop; 2001.

24. Aguilar-Stoen M, Moe SR, Camargo-Ricalde SL: Home gardens sustain crop diversity and improve farm resilience in Candelaria Loxicha, Oaxaca, Mexico. Hum Ecol 2009, 37:55-77.

25. Finerman R, Sackett R: Using home gardens to decipher health and healing in the Andes. Med Anthropol Q 2003, 17(4):459-482.

26. Cai CT, Luo LS, Nan YZ: Energy and economic flow in home gardens in subtropical Yunnan, SW China: a case study on Sanjia village. Int J Sustain Dev World Ecol 2004, 11:199-204.

27. Ali AMS: Home gardens in smallholder farming systems: Examples from Bangladesh. Hum Ecol 2005, 33:245-270.

28. Abdoellah OS, Hadikusumah HY, Takeuchi K, Okubo S, Parikesit: Commercialization of homegardens in an Indonesian village: vegetation composition and functional changes. Agrofor Syst 2006, 68:1-13.

29. Sunwar S, Thornstrom CG, Subedi A, Bystrom M: Home gardens in western Nepal: opportunities and challenges for on-farm management of agrobiodiversity. Biodivers Conserv 2006, 15:4211-4238.
30. Okafor JC, Fernandes ECM: Compound farms of South Eastern Nigeria: a predominant agroforestry homegarden system with crops and small livestock. Agrofor Syst 1987, 5:153-168.

31. Fernandes ECM, Oktingati A, Maghembe J: The Chagga homegardens: a multistoried agroforestry cropping system on Mt. Kilimanjaro, Northern Tanzania. Agrofor Syst 1984, 2:73-86.

32. Faber $\mathrm{M}$, Venter SL, Benade AS: Increased vitamin A intake in children aged 2-5 years through targeted home-gardens in a rural South African community. Public Health Nutr 2002, 5(1):11-16.

33. Drescher AW, Hagmann J, Chuma E: Homegardens - a neglected potential for food security and sustainable land management in the communal lands of Zimbabwe. Der Tropenlandwirt - Beiträge zur tropischen Landwirtschaft und Veterinärmedizin (Journal of Agriculture in the Tropics and Subtropics) 1999, 100:163-180.

34. Thompson JL, Gebauer J, Hammer K, Buerkert A: The structure of urban and peri-urban gardens in Khartoum, Sudan. Genet Resour Crop Evol 2010, 57:487-500.

35. tho Seeth $H$, Chachnov S, Surinov A: Russian poverty: muddling through economic transition with garden plots. World Dev 1998, 26(9):1611-1623.

36. Vogl CR, Vogl-Lukasser B: Tradition, dynamics and sustainability of plant species composition and management in homegardens on organic and non-organic small scale farms in Alpine Eastern Tyrol. Austria. Biol Agric Hortic 2003, 21:149-166.

37. Bassullu C, Tolunay A: General characteristics of traditional homegarden involving animal practices in rural areas of Isparta Region of Turkey. J Anim Vet Adv 2010, 9:455-465.

38. Reyes-García V, Aceituno L, Vila S, Calvet-Mir L, Garnatje T, Jesch A, Lastra JJ, Parada M, Rigat M, Vallès J, Pardo-De Santayana M: Home gardens in three mountain regions of the Iberian peninsula: description, motivation for gardening, and gross financial benefits. J Sustain Agric 2012, 36:249-270.

39. Cleveland DA, Orum TV, Ferguson N: Economic value of home vegetable gardens in an urban desert environment. Hort Sci 1985, 20(4):694-696.

40. Agelet $\mathrm{A}$, Bonet MÀ, Vallès J: Home gardens and their role as a main source of medicinal plants in mountain regions of Catalonia (Iberian Peninsula). Econ Bot 2000, 54:295-309.

41. Calvet-Mir L, Calvet-Mir M, Vaqué-Nuñez L, Reyes-García V: Landraces in situ conservation: A case study in high-mountain home gardens in VallFosca, Catalan Pyrenees, Iberian Peninsula. Econ Bot 2011, 65:146-157.

42. Bleasdale T, Crouch C, Harlan SL: Community gardening in disadvantaged neighborhoods in Phoenix, Arizona: Aligning programs with perceptions. Journal of Agric, Food Syst Community Dev 2010-2011, 3(1):99-114.

43. Ranasinghe TI: Manual of Low/No-Space Agriculture cum-Family Business Gardens. AN Leusden, The Netherlands: RUAF Foundation; 2009.

44. Soemarwoto O, Conway GR: The Javanese homegarden. J Farming Syst Res Ext 1991, 2(3):95-118.

45. Galhena DH, Mikunthan G, Maredia KM: Home Gardens for Enhancing Food Security in Sri Lanka. Farming Matters 2012, 28(2):12.

46. Fernandes ECM, Nair PKR: An evaluation of the structure and function of tropical homegardens. Agr Syst 1986, 21:279-310.

47. Nair PKR: Agroforestry Systems in the Tropics. Dordrecht, The Netherlands: Kluwer Academic Publishers; 1989.

48. Torquebiau E: Are tropical agroforestry gardens sustainable? Agric Ecosyst Environ 1992, 41:189-207.

49. Christanty L, Abdoellah OL, Marten GG, Iskandar J: Traditional agroforestry in West Java: the Pekaranagan (home garden) and Kebun-Talun (annualperennial rotation) cropping systems. In Traditional Agriculture in South East Asia. Edited by Marten GG. Boulder CO, USA: Westview Press; 1986.

50. Asfaw Z: Home Gardens in Ethiopia: Some Observations and Generalizations. Witzenhausen, Germany: Paper presented at Proceedings of the Second International Home Gardens Workshop; 2002.

51. Wiersum KF: Diversity and change in homegarden cultivation in Indonesia. In Tropical Homegardens: A Time-Tested Example of Sustainable Agroforestry. Vol 3. Edited by Nair BMKPKR. Dordrecht, The Netherlands: Springer Science; 2006

52. Perrault-Archambault M, Coomes OT: Distribution of agrobiodiversity in home gardens along the Corrientes River, Peruvian Amazon. Econ Bot 2008, 62(2):109-126.

53. Peyre A, Guidal A, Wiersum KF, Bongers F: Dynamics of homegarden structure and functions in Kerala, India. Agrofor Syst 2006, 66:101-115.

54. Moreno-Black G, Somansang P, Thamathawan S: Cultivating continuity and creating change: woman's home garden practices in northeastern Thailand. Agr Hum Val 1996, 13(3):3-11. 
55. Jacob VJ, Alles WS: The Kandyan gardens of Sri Lanka. Agrofor Sys 1987 5:123-137.

56. Maroyi A: Traditional home gardens and rural livelihoods in Nhema, Zimbabwe: A sustainable agroforestry system. Int J Sustain Dev World Ecol 2009, 16(1):1-8.

57. Turner BL, Hanham RQ, Portararo AV: Population pressure and agricultural intensity. Assoc Am Geogr 1977, 67:384-396.

58. Meertens HCC, Fresco LO, Stoop WA: Farming systems dynamics: Impact of increasing population density and the availability of land resources on changes in agricultural systems. The case of Sukumaland, Tanzania. Agric Ecosys and Environ 1996, 56:203-215.

59. Turner BL, Brush SB: The nature of farming systems and views of their changes. In Comparative Farming Systems. Edited by Turner BL, Brush SB. New York, USA: Guilford Press; 1987

60. Landon-Lane C: Livelihoods Grow in Gardens - Diversifying Rural Income Through Home Garden, Volume 2. Rome, Italy: Food and Agriculture Organization of the United Nations; 2011.

61. Ochse J): Horticulture and its importance in diet research. Landbouw 1937, 13:202-225.

62. Danoesastro $\mathrm{H}$ : The Role of Homegardens as a Source of Additional Daily Income. Bandung, Indonesia: Paper presented at the Seminar on the Ecology of Homegardens III; 1980.

63. Soemarwoto O, Soemarwoto I, Karyono Soekartadireja EM, Ramlan A: The Javanese home garden as an integrated agroecosystem. Food Nutr Bull 1985, 7(3):44-47

64. Michon G, Mary F: Conversion of traditional village gardens and new economic strategies of rural households in the area of Bogor, Indonesia. Agrofor Syst 1994, 25:31-58

65. Thaman RR: Urban food gardening in the Pacific Islands: a basis for food security in rapidly urbanising small-island states. Habitat International 1995, 19(2):209-224.

66. de la Cerda HEC, Mukul RRG: Homegarden production and productivity in a Mayan community of Yucatan. Hum Ecol 2008, 36:423-433.

67. Alam M: Tropical homegardens in Bangladesh: characteristics and sustainability. In Sustainable Agriculture Reviews 6: Alternative Farming Systems, Biotechnology, Drought Stress and Ecological Fertilisation. Edited by Lichtfouse E. Dordrecht, The Netherlands: Springer Science; 2011.

68. Coomes OT, Ban N: Cultivated plant species diversity in home gardens of an Amazonian peasant village in northeastern Peru. Econ Bot 2004, 58(3):420-434

69. Bennett-Lartey SO, Ayernor GS, Markwei CM, Asante IK, Abbiw DK, Boateng SK, Anchirinah VM, Ekpe P: Contribution of Home Gardens to in situ Conservation of Plant Genetic Resources in Farming Systems in Ghana. Witzenhausen, Germany: Paper presented at Proceedings of the Second International Home Gardens Workshop; 2002.

70. Soemarwoto $\mathrm{O}$ : Homegardens: a traditional agroforestry system with a promising future. In Agroforestry: A Decade of Development. Edited by Steppler H, Nair PKR. Nairobi, Kenya: International Council for Research in Agroforestry; 1987.

71. Ali MY, Ahmed MM, Islam MB: Homestead Vegetable Gardening: Meeting the Need of Year Round Vegetable Requirement of Farm Family. Dhaka, Bangladesh Paper presented at the National workshop on Multiple cropping; 2008.

72. Talukder A, Kiess L, Huq N, de Pee S, Darnton-Hill I, Bloem MW: Increasing the production and consumption of vitamin A-rich fruits and vegetables: lessons learned in taking the Bangladesh homestead gardening programme to a national scale. Food Nutr Bull 2000, 21(2):165-172.

73. Asfaw Z, Woldu Z: Crop associations of home gardens in Welayta and Gurage in southern Ethiopia. Ethiopian J Sci 1997, 20:73-90.

74. Abdoellah OS, Gunawan B, Hadikusumah HY: Home Gardens in the Upper Citarum Watershed, West Java: A Challenge for in situ Conservation of Plant Genetic Resources. Witzenhausen, Germany: Paper presented at Proceedings of the Second International Home Gardens Workshop; 2001.

75. Pulami RP, Poudel D: Home Garden's Contribution to Livelihoods of Nepalese Farmers. Pokhara, Nepal: Paper presented at Home Gardens in Nepal: Proceeding of a workshop on Enhancing the contribution of home garden to on-farm management of plant genetic resources and to improve the livelihoods of Nepalese farmers: Lessons learned and policy implications (2004); 2006.

76. Alvarez-Buylla Roces ME, Lazos Chavero E, García-Barrios JR: Homegardens of a humid tropical region in Southeast Mexico: an example of an agroforestry cropping system in a recently established community. Agrofor Syst 1989, 8:133-156.
77. WinklerPrins AMGA: House-lot gardens in Santarém, Para, Brazil: linking rural with urban. Urban Ecosyst 2002, 6(1\&2):43-65.

78. Abebe T, Wiersum K, Bongers F, Sterck F: Diversity and dynamics in homegardens of southern Ethiopia. In Tropical Homegardens: A Time-tested Example of Sustainable Agroforestry. Edited by Nair BMKPKR. Dordrecht, The Netherlands: Springer Science; 2006.

79. Buchmann C: Cuban home gardens and their role in social-ecological resilience. Hum Ecol 2009, 37:705-721.

80. Wezel A, Bender S: Plant species diversity of homegardens of Cuba and its significance for household food supply. Agrofor Syst 2003, 57:39-49.

81. Salam MA, Babu KS, Mohana KN: Home garden agriculture in Kerala revisited. Food Nutr Bull 1994, 16(3):220-223

82. Holden ST, Hvoslef H, Simajuntak R: Transmigration settlements in Seberida, Sumatra. Deterioration of farming system in a rain forest environment. Agr Syst 1996, 49:237-258.

83. Niñez VK: Working at half-potential: constructive analysis of homegarden programme in the Lima slums with suggestions for an alternative approach. Food Nutr Bull 1985, 7(3):6-13.

84. von Grebmer $K$, Torero M, Olofinbiyi T, Fritschel $T$, Wiesmann $D$, Yohannes $Y$, Schofield L, von Oppeln C: The 2011 Global Hunger Index. Bonn, Germany; Washington DC, USA; Dublin, Ireland: International Food Policy Research Institute, Concern Worldwide, and Welthungerhilfe; 2011.

85. Iannotti L, Cunningham K, Ruel M: Improving Diet Quality and Micronutrient Nutrition: Homestead Food Production in Bangladesh. Washington DC, USA: International Food Policy Research Institute; 2009. Discussion Paper 00928

86. Wanasundera L: Rural Women in Sri Lanka's Post-Conflict Rural Economy. Colombo, Sri Lanka: International Labor Office; 2006. RAP Publication 13.

87. Helen Keller International - Asia-Pacific: Homestead food production model contributes to improved household food security, nutrition and female empowerment - experience from scaling-up programs in Asia (Bangladesh, Cambodia, Nepal and Philippines). Nutr Bull 2010, 8(1):1-8.

88. Bandarin F, Hosagrahar J, Albernaz FS: Why development needs culture. J Cult Herit Manag Sustain Dev 2011, 1(1):15-25.

89. Rao MR, Rajeswara Rao BR: Medicinal plants in tropical homegardens. In Tropical Homegardens: A Time-tested Example of Sustainable Agroforestry. Edited by Kumar BM, Nair PKR. Dordrecht, The Netherlands: Springer Science; 2006

90. Perera AH, Rajapakse RMN: A baseline study of Kandyan forest gardens of Sri Lanka: structure, composition and utilization. For Ecol Manage 1991, 45:269-280.

91. Millat-e-Mustafa M, Teklehaimanot Z, Haruni AKO: Traditional uses of perennial homestead garden plants in Bangladesh. Forests Trees Livelihoods 2002, 12:235-256.

92. Rugalema GH, Okting'ati A, Johnsen FH: The homegarden agroforestry system of Bukoba district, Northwestern Tanzania. 1. Farming system analysis. Agrofor Syst 1994, 26:53-64.

93. Rico-Gray V, Chemas A, Mandujano S: Use of tropical deciduous forest species by the Yucatecan Maya. Agrofor Sys 1991, 14:149-161.

94. De Clerck FAJ, Negreros-Castillo P: Plant species of traditional Mayan homegardens of Mexico as analogs for multistrata agroforests. Agrofor Sys 2000, 48:303-317.

95. World Health Organization: Global Health Risks: Mortality and Burden of Disease Attributable to Selected Major Risks. Geneva, Switzerland: World Health Organization; 2009.

96. West KP Jr, Darnton-Hill I: Vitamin A deficiency. In Nutrition and Health in Developing Countries. Edited by Semba RD, Bloem MW. Totowa NJ, USA: Humana Press; 2008.

97. Stoltzfus R, Mullany L, Black R: Iron deficiency anaemia. In Comparative Quantification of Health Risks: Global and Regional Burden of Disease Attributable to Selected Major Risk Factors. Edited by Ezzati M, Lopez A, Rodgers A, Murray C. Geneva, Switzerland: World Health Organization; 2004.

98. de Benoist B, Darnton-Hill I, Davidsson L, Fontaine O, Hotz C: Conclusions of the joint WHO/UNICEF/IAEA/IZiNCG interagency meeting on zinc status indicators. Food Nutr Bull 2007, 28(3):S480-S79.

99. Black R, Allen L, Bhutta Z, Caulfield L, de Onis M, Ezzati M, Mathers C, Rivera $\mathrm{J}$ : Maternal and child undernutrition: global and regional exposures and health consequences. Lancet 2008, 371(9608):243-260.

100. Talukder A, Sapkota G, Shrestha S, de Pee S, Bloem MW: Homestead Food Production Program in Central and Far-Western Nepal Increases Food and Nutrition Security: An Overview of Program Achievements. Pokhara, Nepal: Paper presented at Home Gardens in Nepal: Proceeding of a workshop on Enhancing the contribution of home garden to on-farm management of 
plant genetic resources and to improve the livelihoods of Nepalese farmers: Lessons learned and policy implications (2004); 2006.

101. Bloem M, de Pee S, Darnton-Hill I: New issues in developing effective approaches for the prevention and control of vitamin A deficiency. Food Nutr Bull 1998, 19(2):137-148.

102. Keys E, Kaqchikel G: Women, Children, and Multiple Roles of Gardens among the Maya of Highland Guatemala. Yearbook, Conference of Latin Americanist Geographers. Austin TX, USA: Paper presented at Conference of Latin Americanist Geographers; 1999.

103. Pandey $C B$, Rai $R B$, Singh $L$, Singh $A K$ : Homegardens of Andaman and Nicobar, India. Agr Syst 2007, 92:1-22.

104. Howard PL: Gender and social dynamics in swidden and homegardens in Latin America. In Tropical Homegardens: A Time-Tested Example of Sustainable Agroforestry. Edited by Nair BMKPKR. Heidelberg, The Netherlands: Springer Science; 2006.

105. Descola P: In the Society of Nature: A Native Ecology in Amazonia. New York, USA: Cambridge University Press; 1994.

106. Brun T, Reynaud J, Chevaussus-Agnes S: Food and nutrition impact of one home garden project in Senegal. Ecol Food Nutr 1989, 23:91-108.

107. Kumar SK: Role of the Household Economy in Child Nutrition at Low Incomes: A Case Study in Kerala. Ithaca NY, USA: Department of Agricultural Economics, Cornell University; 1978. Occasional Paper No. 95.

108. Adhikari A, Singh D, Suwal R, Shrestha PK, Gautam R: The Role of Gender in the Home Garden Management and Benefit-Sharing from Home Gardens in Different Production System of Nepal. Pokhara, Nepal: Paper presented at Home Gardens in Nepal: Proceeding of a workshop on Enhancing the contribution of home garden to on-farm management of plant genetic resources and to improve the livelihoods of Nepalese farmers: Lessons learned and policy implications (2004); 2006.

109. Soemarwoto O: The Javanese rural ecosystem. In An Introduction to Human Ecology Research on Agricultural Systems in Southeast Asia. Edited by Rambo AT, Sajise PE. Los Banos, The Philippines: University of Philippines; 1984.

110. Blanckaert I, Swennen RL, Paredes Flores M, Rosas López R, Lira SR: Floristic composition, plant uses and management practices in homegardens of San Rafael Coxcatlán. Valle de Tehuacán-Cuicatlán, México. J Arid Environ 2004, 57:39-62.

111. Trinh LN, Watson JW, Hue NN, De NN, Minh NV, Chu P, Sthapit BR, Eyzaguirre PB: Agrobiodiversity conservation and development in Vietnamese home gardens. Agric Ecosyst Environ 2003, 97:317-344.

112. Calvet-Mir L, Gómez-Bagetthun E, Reyes-García V: Beyond food production: Home gardens" ecosystem services. A case study in Vall Fosca, Catalan Pyrenees, northeastern Spain. Ecol Econ 2012, 74:153-160.

113. Vasey DE: Household gardens and their niche in Port Moresby, Papua New Guinea. Food Nutr Bull 1985, 7(3):37-43.

114. Kehlenbeck K, Maass BL: Crop diversity and classification of homegardens in Central Sulawesi, Indonesia. Agrofor Syst 2004, 63:53-62.

115. Okigbo B: Home Gardens in Tropical Africa. In Tropical Home Gardens. Edited by Landauer K, Brazil M. Tokyo, Japan: United Nations University Press; 1990.

116. Wilson RT: Livestock Production Systems. London, UK: Macmillan; 1995.

117. Devendra C, Thomas D: Smallholder farming systems in Asia. Agr Syst 2002, 71:17-25.

118. Albuquerque UP, Andrade LHC, Caballero J: Structure and floristics of homegardens in Northeastern Brazil. J Arid Environ 2005, 62:491-506.

119. Watson JW, Eyzaguirre PB: Homegardens and in-situ Conservation of Plant Genetic Resources in Farming Systems. Witzenhausen, Germany: Paper presented at 2nd International Homegarden Workshop; 2002.

120. Gajaseni J, Gajaseni N: Ecological rationalities of the traditional homegarden system in the Chao Phraya Basin, Thailand. Agrofor Syst 1999, 46:3-23.

121. Pushpakumara DKNG, Wijesekara A, Hunter DG: Kandyan homegardens: A promising land management system in Sri Lanka. In Sustainable use of Biological Diversity in Socio-ecological Production Landscapes. Background to the 'Satoyama Initiative for the Benefit of Biodiversity and Human Well-being'. Edited by Bélair C, Ichikawa K, Wong BYL, Mulongoy KJ. Montreal, Canada: The Secretariat of the Convention on Biological Diversity; 2010.

122. Christanty L: Home Gardens in Tropical Asia, with Special Reference to Indonesia. In Tropical Home Gardens. Edited by Landauer K, Brazil M. Tokyo, Japan: United Nations University Press; 1990.
123. Seneviratne G, Kuruppuarachchi KAJM, Somaratne S, Seneviratne KACN: Nutrient cycling and safety-net mechanism in the tropical home gardens. Int J Agric Res 2010, 5(7):529-542.

124. Terra GJA: Mixed-garden horticulture in Java. Malayan Journal of Top Geogr 1954, 3:33-43.

125. Powell JM, Williams TO: Livestock, Nutrient Cycling and Sustainable Agriculture in the West African Sahel. London, UK: International Institute for Environment and Development; 1993. Gatekeeper Series No. 37.

126. McConnell DJ, Dharmapala KAE: The Economic Structure of Kandyan Forest Garden Farms. Peradeniya, Sri Lanka: UNDP/SF/FAO Diversification Project; 1973.

127. Pushkaran K: Home Gardens in Kerala as an Efficient Agroecosystem for Conservation and Sustainable Management of Biodiversity. Witzenhausen, Germany: Paper presented at Proceedings of the Second International Home Gardens Workshop: Contributions of home gardens to in situ conservation of plant genetic resources in farming systems; 2002.

128. Perera AH: Role of Kandyan Forest Gardens in Germplasm Conservation. Peradeniya, Sri Lanka: Paper presented at the regional workshop on conservation methodology in South Asia; 1988.

129. Senanayake FR: Analog forestry as conservation tool. Tiger Paper 1987, 15:25-28.

130. Hochegger K: Farming like the forest: traditional home garden systems in Sri Lanka. Weikersheim, Germany: Margraf Verlag; 1998.

131. Kumarathunga N: Mihikatha Surakina Parisara Govikama. Nugegoda, Sri Lanka: Govikam Asiriya 2; 2008.

132. Jose D, Shanmugaratnam N: Traditional homegardens of Kerala: a sustainable human ecosystem. Agrofor Sys 1993, 24:203-213.

133. Thaman RR: "Urban root crop production in South West Pacific". In Regional meeting on the production of root crops. Technical paper - South Pacific Commission; 1977:73-82.

134. Evers G, Keleta E, Kirway T: A farming system study in the lowland wet zone of Sri Lanka, Agalawatta Division, Kalutara District. Wageningen, The Netherlands: International Course for development oriented Research in Agriculture; 1985.

135. Miura S, Osamu K, Susumu W: Home gardening in urban poor communities of the Philippines. Int J Food Sci Nutr 2003, 54(1):77-88.

136. Food and Agriculture Organization: An Introduction to the Basic Concepts of Food Security. Rome, Italy: Food Security Information for Action, Practical Guides; 2008.

137. Food and Agriculture Organization: World Agriculture: Towards 2030/2050 Rome, Italy: Interim report; 2006.

138. Alexandratos N: World Food And Agriculture to 2030/2050: Highlights and Views From mid-2009. Rome, Italy: In Proceedings from FAO Expert Meeting on How to Feed the World in 2050; 2009.

139. Food and Agriculture Organization: An Introduction to the Basic Concepts of Food Security. Food Security Information for Action, Practical Guides. Rome, Italy: EC - FAO Food Security Programme; 2008.

140. United States Department of Agriculture: Definitions of Food Security. http://www.ers.usda.gov/topics/food-nutrition-assistance/food-security-inthe-us/measurement.aspx (accessed January 2013).

141. Pinstrup-Andersen P: Food security: definition and measurement. Food Secur 2009, 1(1):5-7.

142. Gasser M, Salzano C, Meglio RD, Lazarte-Hoyle A: Post-crisis Situations: Problems and Needs. Local Economic Development In Post-Crisis Situations: Operational Guide. International Labour Organization: Geneva, Switzerland; 2004.

\section{doi:10.1186/2048-7010-2-8}

Cite this article as: Galhena et al:: Home gardens: a promising approach to enhance household food security and wellbeing. Agriculture \& Food Security 2013 2:8. 